\title{
Implementasi Algoritma Lzss pada Aplikasi Kompresi dan Dekompresi File Dokumen
}

\author{
JASMAN PARDEDE,MIRA MUSRINI B, LUQMAN YUDHIANTO
}

\author{
Jurusan Teknik Informatika, Fakultas Teknologi Industri \\ Institut Teknologi Nasional Bandung \\ Email: sangkuriang26@yahooo.com
}

\begin{abstract}
Informasi yang bersifat dinamis dan berubah dalam hitungan detik harus dikirimkan saat itu juga agar informasi yang didapat sesuai dengan keadaan. Dokumen yang berukuran besar menimbulkan masalah bila kecepatan unggah pengirim lambat atau kecepatan unduh penerima lambat atau koneksi internet tidak stabil, informasi tidak bisa langsung diproses dikarenakan waktu transfer data yang terlampau lama. Kompresi file dibutuhkan agar dokumen yang dikirimkan dapat lebih kecil dari ukuran aslinya sehingga waktu pengiriman file dokumen tidak terlalu lama. Dalam penelitian ini dikembangkan aplikasi kompresi fileteks dengan menggunakan metode Lempel Ziv Storer Szymanski (LZSS) dengan menggunakan bahasa pemograman java. Metode Lempel Ziv Storer Szymanski mencari kesamaan string antara dictionary buffer dan look ahead buffer menghasilkan token yang ukuran lebih kecil dari string yang diwakili. Berdasarkan pengujian aplikasi, file teks yang berformat. doc menghasilkan rasio kompresi terbaik yaitu 30\%. Metode Lempel Ziv Storer Szymanski bekerja dengan baik pada file teks yang isinya tidak memiliki gambar.
\end{abstract}

Kata kunci : Dokumen, Algoritma LZSS, Kompresi

\begin{abstract}
The information that dynamic and changing in seconds should be sent at that time so the information obtained realtime. Large document will cause problems when the sender upload speedwas slow or recipient download speedwas slow or theinternet connection unstable, the information can not be processed due data transfer timewas delayed. File compression is needed to reduce the sizeof document that will be sent to smaller than original sizeso the delivery time is not delayed. In this research will develop a document file compression application using Lempel Ziv Storer Szymanski (LZSS) using java programming language.Lempel Ziv Storer Szymanski method looking for similarities between the dictionary string buffer and look ahead buffer produces tokens that the smaller size of the string being represented. According to the application test, text file that .doc extension produces the best compression ratio that is 30\%. Lempel Ziv Storer Szymanski works good on text file that not contained any picture.
\end{abstract}

Keyword: Document, LZSS Algorithm, Compression 


\section{PENDAHULUAN}

Informasi penting yang dikirim dari satu instansi ke instansi lain membutuhkan waktu pengiriman data yang cepat agar informasi yang didapat sesuai dengan keadaan yang terbaru. Isi dari dokumen tersebut berkembang tiap waktunya dan menghasilkan file dokumen yang semakin besar. Untuk dapat mengirim dokumen berukuran besar sesegera mungkin dengan kecepatan unggah yang lambat dibutuhkan suatu solusi yaitu dengan teknik kompresi data.

Kompresi data adalah suatu teknik mengubah data menjadi bentuk data lain dimana data tersebut diubah menjadi simbol yang lebih sederhana. Kompresi data mempunyai tujuan memperkecil ukuran data tanpa merubah isi dari data tersebut sehingga selain dapat menghemat media penyimpanan juga memudahkan transfer data.

Terdapat banyak metode kompresi/osslesssalah satu Metode Lempel Ziv Storer Szymanski (LZSS). LZSS menghasilkan kode-kode untuk karakter dengan cara membentuk "dictionary". Sedangkan perbedaannya dengan LZ77 dimana "dictionary" harus dibentuk setiap data didekompresi ulang sedangkan pada LZSS hanya suatu urutan dengan panjang minimum tertentu yang dikodekan. Metode LZSS menggunakan trik khusus yaitu menggunakan bit flag yang hanya satu bit saja yang memberitahukan data apa berikutnya dan untuk membedakan antara isi tidak terkompresi dengan menggunakan pointer. Ini tentunya berpengaruh pada waktu proses.

Oleh karena dirancang sebuah aplikasi yang dapat mengkompresi dan dekompres file dokumen menggunakan metode Lempel Ziv Storer Szymanski (LZSS)

\section{METODOLOGI PENELITIAN}

\subsection{KompresiData}

Kompresi berarti memampatkan mengecilkan ukuran.Kompresi data adalah proses mengkodekan informasi menggunakan bit atau information-bearing unit yang lain yang lebih rendah daripada representasi data yang tidak terkodekan dengan suatu sistem encoding tertentu. Contoh kompresi sederhana yang biasa dilakukan misalnya adalah menyingkat katakata yang sering digunakan tapi sudah memiliki konvensi umum.Misalnya : kata "yang" dikompres menjadi kata "yg". Kompresi data teks dan citra digital adalah proses untuk meminimalisasi jumlah bit yang merepresentasikan suatu data baik berupa teks maupun citra/gambar sehingga ukuran data menjadi lebih kecil. Pengiriman data hasil kompresi dapat dilakukan jika pihak pengirim atau pihak penerima memiliki aturan yang sama dalam hal kompresi data [1].

\subsection{Lempel Ziv Storer Szymanski (LZSS)}

Algoritma Lempel Ziv Storer Symanski (LZSS) adalah algoritma kompresi data lossless yang dimodifikasi dari LZ77, dinamai penciptanya James Storer dan Thomas Szymanski (yang dibangun di atas karya Abraham Lempel dan Jacob Ziv). Algoritma Lempel Ziv Storer Symanski (LZSS) salah satu kompresi urutan simbol data (misalnya, byte data) dengan mengidentifikasi urutan simbol yang berulang dalam masukan, dan menggantikan urutan-urutan simbol yang lebih kecil. Implementasi Lempel Ziv Storer Symanski (LZSS) dapat menyesuaikan jumlah bit yang dialokasikan dengan mengganti panjang ukuran byte (antara parameter lain) untuk mendapatkan kinerja kompresi yang cukup baik [2]. 


\subsubsection{Algoritma Lempel Ziv Storer Symanski (LZSS)}

Algoritma untuk Lempel Ziv Storer Symanski (LZSS) [2] adalah sebagai berikut :

1. Tempatkan posisi koding pada permulaan masukan stream.

2. Cari longest match pada window untuk lookahead buffer,

a. $\mathrm{P}=$ pointer untuk mencocokan;

b. $L=$ panjang masukan yang cocok;

3. Apakah $L>=$ MIN_LENGTH?

a. Jika YA :keluarannya P dan bergerak ke posisi L karakter;

b. Jika TIDAK : keluarannya karakter pertama pada lookhead buffer dan bergerak satu posisi karakter ke depan;

4. Jika karakter masukan stream banyak, ulangi langkah 2.

\section{Window dan Match Lengt}

Ada beberapa aturan agar sistem dapat bekerja yaitu:

a. Untuk flag mengidentifikasi sebuah literal atau cocok

b. Seberapa jauh data sebelumnya dapat dicocokan.

c. Jumlah bytes maksimum yangdapat dicocokan. Untuk aturan yang pertama hanya membutuhkan dua flag yaitu literal atau cocok, jadi hanya menggunakan bit tunggal. Jika menggunakan bit tunggal maka seluruh bytes tidak selalu ditulis tapi hanya sebagian saja. Sebelum proses pemampatan dilakukan, dibutuhkan suatu fungsi kode untuk membaca dan menulis jumlah variable bit dari atau ke data stream. Sebagai contoh : batas offset menggunakan 4 bits, jadi rangenya antara 0-31. Sedangkan untuk len menggunakan 3 bits jadi range nya antara $0-7$. Keluarannya ditulis menjadi $(4,3)$ dalam byte menjadi " 1 0100011". 1 bit pertama menunjukan flag, diikuti 4bits berikutnya yang menunjukan offset, kemudian 3bits berikutnya menunjukan length [2].

\section{Canterbury Corpus}

Corpus adalah kumpulan data standar yang digunakan dalam mengevaluasi terhadap suatu kompresiloseless secara empiris. Canterbury Corpus merupakan kumpulan corpus dari data yang sering digunakan di masa sekarang. Canterbury Corpus merupakan hasil riset seorang doktor yang bernama Jeff Ghilchrist dari Universitas Carleton, Ottawa, Kanada [3]. Berikut file teks yang diambil dari Canterbury Corpus yang digunakan dalam penelitian ini ditampilkan pada Tabel 1.

Tabel 1.File Teks Canterbury Corpus
\begin{tabular}{|c|c|c|}
\hline Kode & File & Ukuran (byte) \\
\hline C1 & Alice29.txt & 152089 \\
\hline C2 & Asyoulik.txt & 125179 \\
\hline C3 & Lcet10.txt & 426754 \\
\hline C4 & 1musk10.txt & 1344739 \\
\hline C5 & World95.txt & 2993596 \\
\hline
\end{tabular}

\section{Studi Kasus}

Pada studi kasus digunakan sebuah kalimat yang dikompresi algoritma LZSS yaitu "As she said these words"

Langkah ke 1 :

Menentukan besar sliding windows, diasumsikan sliding windows sebesar 21 byte dengan 16 byte dictionary buffer dan 5 byte dictionary buffer. Sliding windows ditampilkan seperti 


$$
\begin{aligned}
& \text { As_she_said_these_words_ } \\
& \text { Dict Buffer Look Buffer }
\end{aligned}
$$

Langkah ke 2 :

Hitung banyak node yang dimasukkan pada binary search tree.Node dihitung dengan rumus. Tnode $=$ Panjang Dictionary Buffer - Panjang Look Ahead Buffer +1

Tnode $=16-5+1=12$ Node

Panjang karakter node sama dengan panjang look ahead buffer yaitu 5 byte (karakter). Setelah banyak node dan panjang node ditemukan maka dilakukan pemberian offset pada setiap node sebagai pointer. Offset dihitung dari sisi kanan dictionary buffer. Hasil pemberian offset pada dictionary buffer seperti

$$
\begin{array}{ll}
\text { _thes } & 00 \\
\text { d_the } & 01 \\
\text { id_th } & 02 \\
\text { aid_t } & 03 \\
\text { said_ } & 04 \\
\text { _said } & 05 \\
\text { e_sai } & 06 \\
\text { he_sa } & 07 \\
\text { she_s } & 08 \\
\text { _she_ } & 09 \\
\text { s_she } & 10 \\
\text { As_sh } & 11
\end{array}
$$

Langkah ke 3 :

Masukkan node yang ditemukan ke dalam binary search tree berdasarkan prinsip lexicongraphic order.Tinggi pohon didapat dari rumus $\log _{2} T$ node dan hasil tinggi pohon 4 tingkat. Binary search tree yang terbentuk seperti pada padagambar 1 .

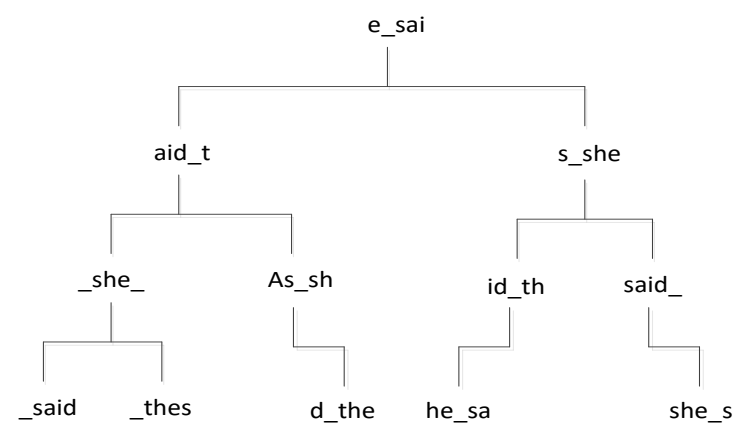

Langkah ke 4 :

Gambar 1. Binary Search Tree

Membandingkan karakter awal pada look ahead buffer dengan node yang ada pada dictionary buffer. Karakter awal pada awal look aheadbufferadalah e dan terjadi cocok dengan node yang ada pada dictionary buffer. Pada offset 11 dan panjang cocok sebesar 2 karakter. Maka token dihasilkan ada $(0,11,2)$ dimana 0 adalah bit flag match, 11 adalah offset, dan 2 adalah panjang karakter cocok. Maka kalimat yang terkompresi menjadi seperti. 
Langkah ke 4:

As she said thes $(0,11,2)$ words

Karena terjadi cocok maka sliding windows bergeser sepanjang cocok yaitu 2 karakter.Sliding windows pun menjadi seperti

$$
\text { As_she_said_these_words_- }
$$

Setelah sliding windows bergeser maka node yang ada binary search tree harus diperbaharui seperti dengan menghapus node As_sh dan s_she dan memasukkan node baru these dan hese_. Lalu lakukan langkah 2 kembali.

Proses kompresi terus berlangsung hingga pembacaan teks selesai dan file teks akan terkompresi.

\section{Penghitungan Durasi Kompresi}

Pada penghitungan durasi ini fungsi java yang digunakan adalahsystem.currentTimeMiliis() yangberguna untuk mengambil waktu saat ini dalam satuan milidetik, dihitung sejak 1 Januri 1970 waktu GMT. Satu milidetik sama dengan 1 per 1000 detik. Keluarannya bertipe long.

Untuk menghitung waktu yang diperlukan untuk menjalankan suatu perintah, jalankan fungsi System.currentTimeMilis() sebelum dan sesudah suatu instruksi dijalankan. Perbedaannya adalah waktu yang diperlukan untuk menjalankan suatu instruksi. Berikut cara penulisan dalam program ditampilkan pada Gambar 2.

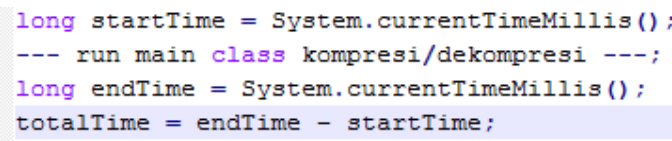

\section{Gambar 2, Penghitungan Durasi Kompresi}

\subsection{Analisis Pengumpulan Data}

Pada pengumpulan data terdapat file teks yang digunakan dalam melakukan kompresi data dokumen. Kumpulan teks yang digunakan dalam mengecek kemampuan dari aplikasi yang dibangun diambil dari Canterbury Corpusseperti yang dijelaskan pada sub bab 2.5.

Selain file teks dari Canterbury Corpus, pengujian juga menggunakan file teks lain. File teks tersebut memiliki berbagai karakteristik. Jenis file teks yang digunakan adalah buku teknik dan buku non teknik.

File teks tersebut ditampilkan pada Tabel 2. 


\begin{tabular}{|c|c|c|}
\hline Kode & File & $\begin{array}{c}\text { Ukuran } \\
\text { (byte) }\end{array}$ \\
\hline P1 & 11.IGIBook1.pdf & 5562768 \\
\hline P2 & b11.pdf & 3832502 \\
\hline P3 & First Course On Fuzzy Theory and Application.pdf & 2403653 \\
& & \\
\hline P4 & JAVA3elatest.pdf & 3596723 \\
\hline P5 & Wiley.Interscience.Fuzzy.Expert.Systems.and.Fuzzy.Reasoning.Dec.2004.eBook- & 2926192 \\
\hline P6 & DDU.pdf & 284672 \\
\hline P7 & Breadwinner.doc & 333824 \\
\hline P8 & frogs.doc & 59392 \\
\hline P9 & James.doc & 2173034 \\
\hline P10 & Little_Women_NT.pdf & 718848 \\
\hline
\end{tabular}

\subsection{Analisis Sistem}

Setelah analisis pengumpulan dilakukan, tahap selanjutnya adalah merancang sebuah desain yang menjelaskan cara kerja sistem aplikasi kompresifile dengan metode LZSS ini.

Tahap sistem kerja aplikasi kompresi ini adalah sebagai berikut :

a) Pengguna membuka aplikasi.

b) File teks dipilih oleh pengguna lalu ditampilkan pada aplikasi.

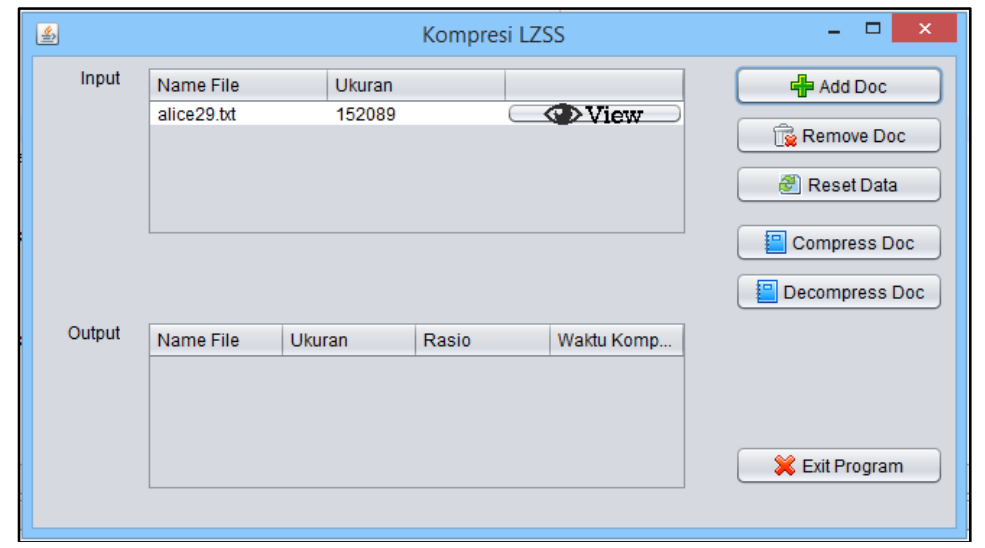

Gambar 3. Tampilan File Terpilih

c) Pengguna melakukan kompresi pada file teks yang sudah dipilih. Proses kompresi dilakukan seperti pada studi kasus.

d) Hasil keluaran dari proses kompresi adalah file teks terkompresi dengan format .Izss, rasio kompresi yang ditunjukkan dalam bentuk persen, dan durasi kompresi yang ditunjukkan dalam satuan milisekon. 
Implementasi Algoritma Lzss pada Aplikasi Kompresi dan Dekompresi File Dokumen

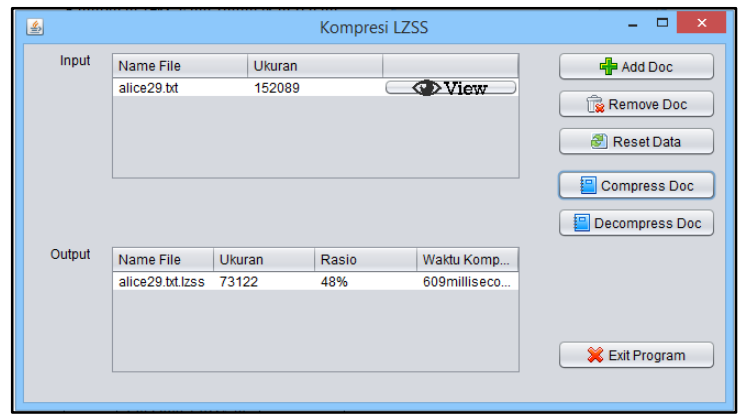

Gambar 4 Tampilan Output

Analisis sistem sudah dilakukan, hasil analisis tersebut dipetakan dalam bentuk flowchart. Berikut gambaran sistem kerja dari aplikasi kompresifile ini ditampilkan padagambar 5 .

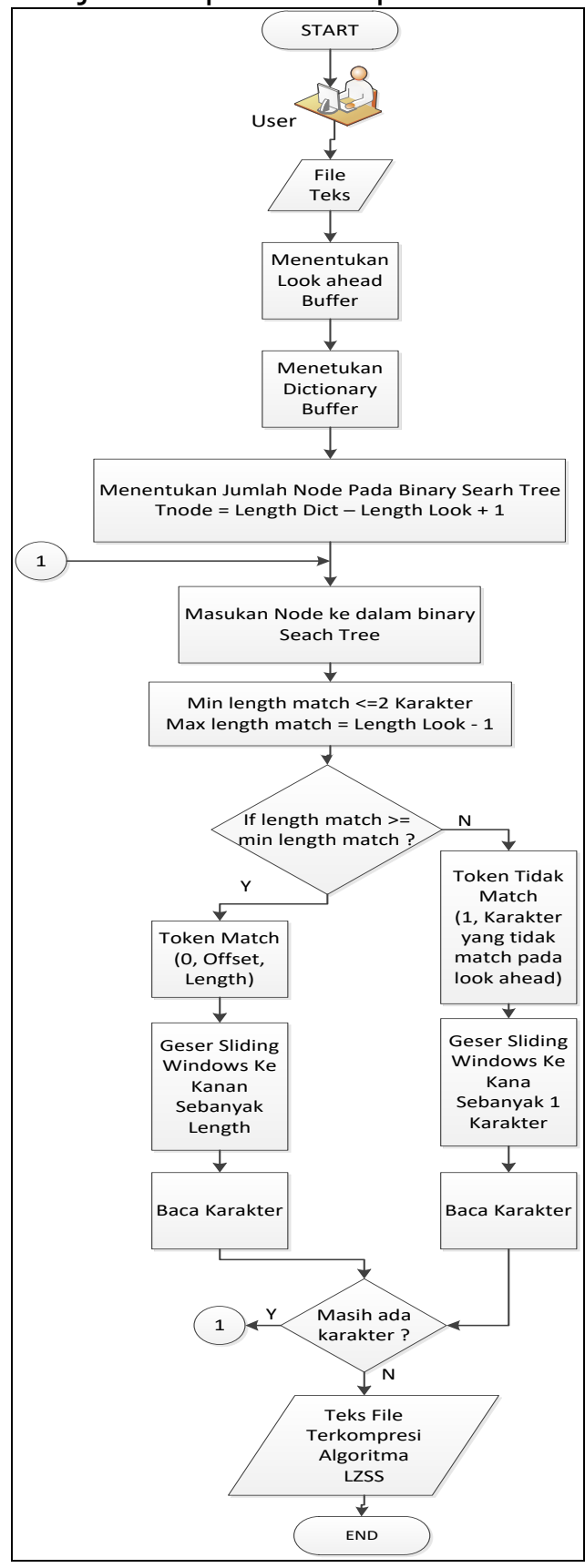

Gambar 5. Flowchart Sistem Kerja Aplikasi 


\section{ANALISIS DAN PEMBAHASAN}

\subsection{Perancangan Sistem}

Perancangan sistem ini menggunakan UML.Berdasarakan analisis yang telah dilakukan. Berikut merupakan proses pengembangan yang dimodelkan dalam bentuk use case diagram. Use case diagram dari proses utama yang terjadi pada pengembangan aplikasi ditampilkan pada Gambar 6.

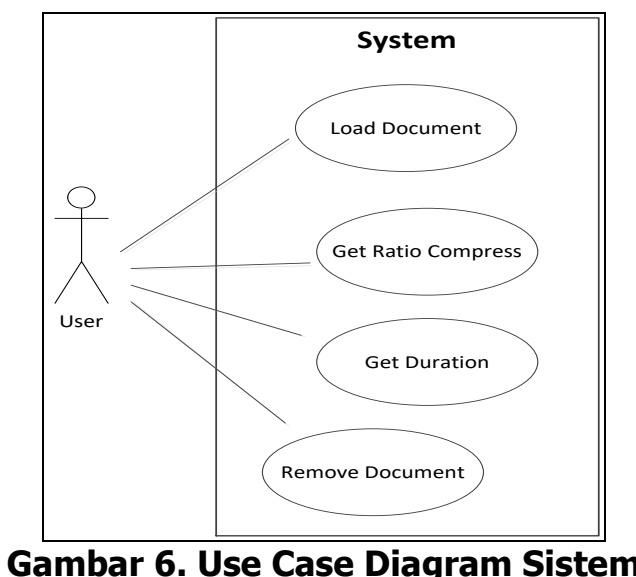

Setelah use case diagram dirancang. Berikut class diagram dari sistem yang telah dibangun, ditampilkan pada Gambar 7.

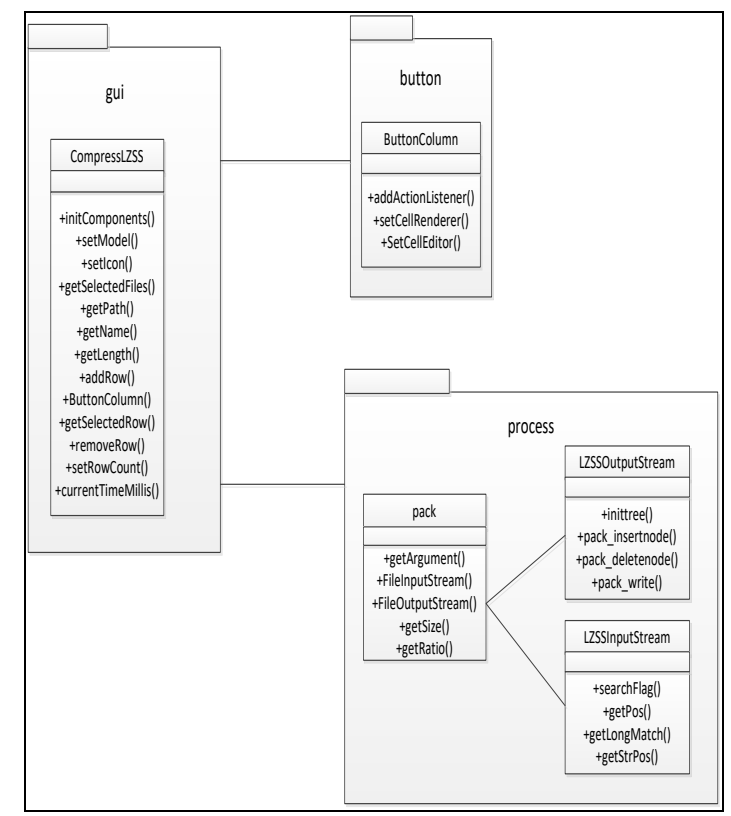

Gambar 7. Class Diagram Sistem

\subsection{Perancangan Layout}

Berikut perancangan layout untuk antar muka aplikasi yang telah dibangun ditampilkan pada Gambar 8. 


\section{Dimana :}

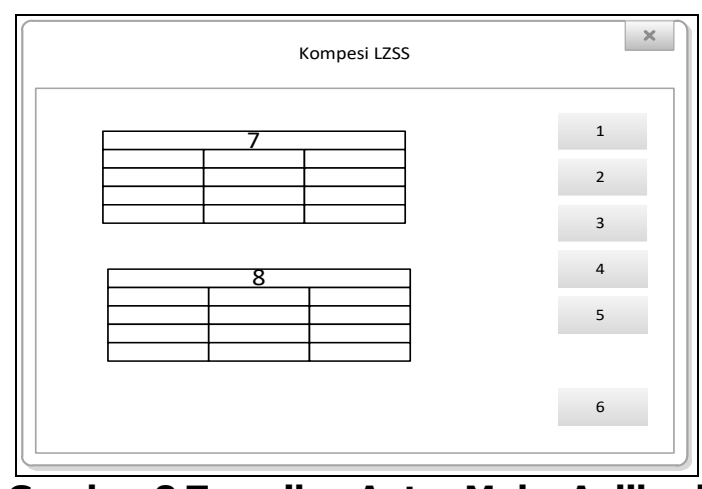

Gambar 8 Tampilan Antar Muka Aplikasi

1. Tombol Add Doc

2. Tombol Remove Doc

3. Tombol Reset Data

4. Tombol Compress Doc

5. Tombol Decompress Doc

6. TombolKeluar Program

7. TabelDataMasukan

8. TabelDataKeluaran

\subsection{Pengujian Fungsional}

Setelah melakukan perancangan, tahap selanjutnya adalah implementasi sistem yang sudah dibangun.Berikut merupakan tampilan hasil dan pengujian fungsional aplikasi.

1. Tampilan Form Utama

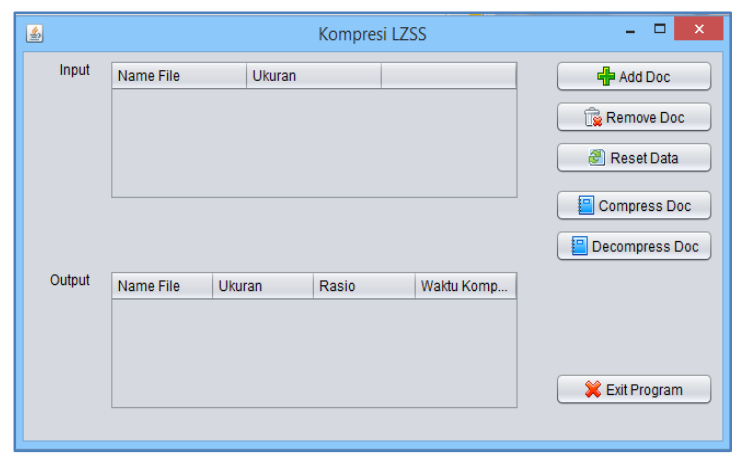

Gambar 9 Tampilan Form Utama

2. Tampilan Pengujian Tambah File

Selanjutnya dilakukan penambahan file yang dikompresi dengan menekan tombol add doc seperti pada Gambar 10.

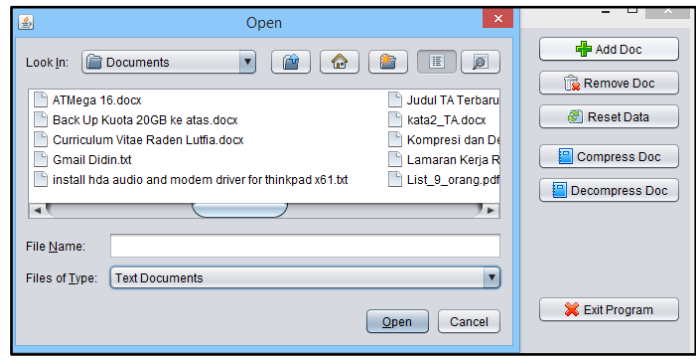

Gambar 10 Tampilan Pilih File 
Setelah memilih pengguna menekan tombolopen.Hasilnya seperti pada Gambar 11.

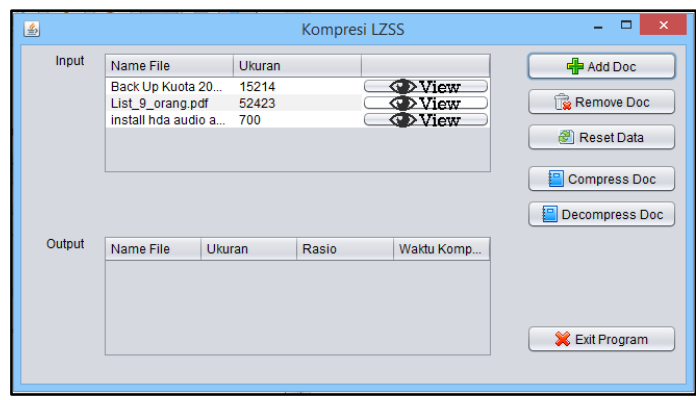

Gambar 11. Data Terpilih Ditampilkan

3. Tampilan Pengujian Nilai Rasio dan Durasi Kompresi

Setelah file berhasil ditambahkan, untuk mendapatkan rasio dan durasi kompresi dengan menekan tombol compress doc. Hasilnya seperti pada gambar 12 .

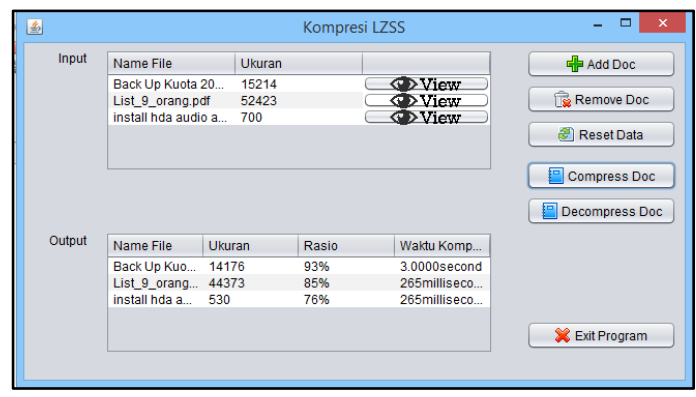

\section{Gambar 12. Hasil Pengujian Nilai Rasio dan Durasi Kompresi}

4. Tampilan Pengujian Hapus File

Jika pengguna ingin menghapus file dari tabelmasukan, pertama pengguna menekan salah satu baris pada tabelmasukan lihat Gambar 13.

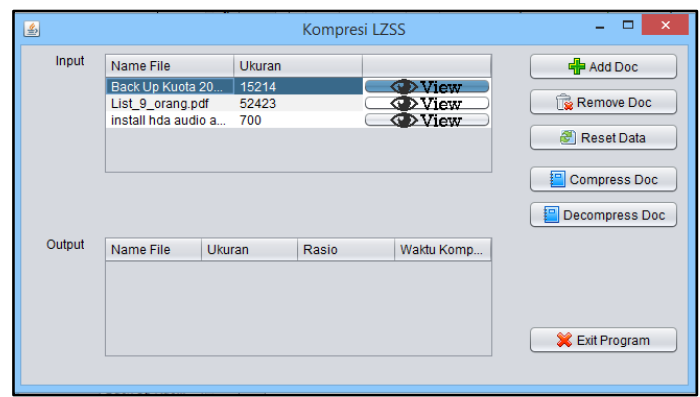

Gambar 13. Klik Data Yang Dihapus

Lalu pengguna menekan tombolremovedoc dan peringatan penghapusan muncul lalu pilih yeslihat pada Gambar14. 


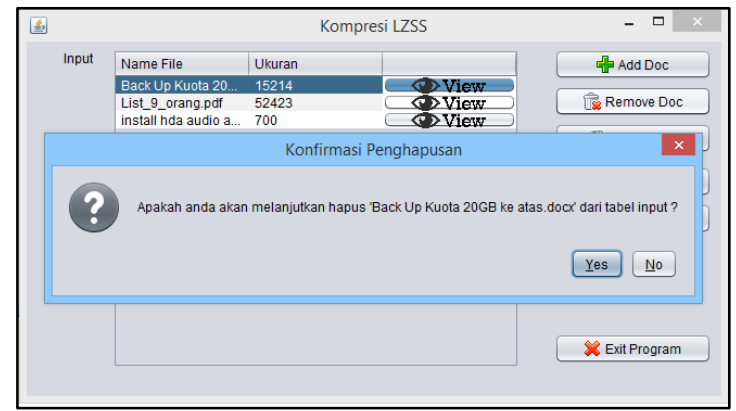

Gambar 14. Peringatan Penghapusan

Maka file terpilih terhapus dan windows pemberitahuan bahwa fileteks terpilih terhapus ditampilkan seperti pada Gambar 15.

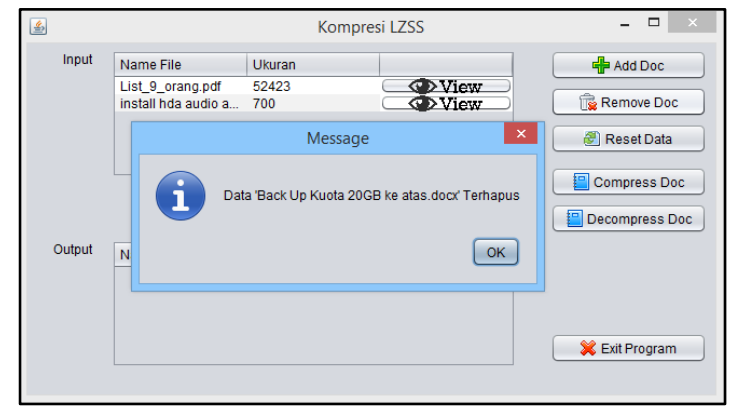

Gambar 15. Data Terpilih Terhapus

\subsection{Pengujian Sistem}

Setelah melakukan pengujian secara fungsional, selanjutnya pengujian sistem dimana untuk mengetahui kemampuan aplikasi kompresi yang telah dibangun.Pengujian ini bertujuan untuk melihat hasil rasio kompresi dan durasi kompresi.Data yang dipakai dalam pengujian ada di Tabel 1 dan Tabel 2.Berikut adalah hasil dari pengujian dari masing-masing data.

3.4.1 Pengujian Rasio dan Durasi Kompresi pada File Teks Dari Canterbury Corpus Hasil pengujian rasio dan durasikompresi ditunjukkan pada Tabel 3.

Tabel 3. Hasil Pengujian Rasio dan Durasi Kompresi Canterbury Corpus

\begin{tabular}{|c|c|c|c|c|}
\hline Kode & $\begin{array}{c}\text { Ukuran Sebelum } \\
\text { Kompresi(byte) }\end{array}$ & $\begin{array}{c}\text { Ukuran Sesudah } \\
\text { Kompresi (byte) }\end{array}$ & Rasio (\%) & $\begin{array}{c}\text { Durasi } \\
\text { (ms) }\end{array}$ \\
\hline C1 & 152089 & 73122 & 48 & 875 \\
\hline C2 & 125179 & 65555 & 52 & 344 \\
\hline C3 & 426754 & 199727 & 47 & 1000 \\
\hline C 45 & 1344739 & 665536 & 50 & 4000 \\
\hline C5 & 2993596 & 1580209 & 53 & 6000 \\
\hline
\end{tabular}

Dari hasil pengujian pada Tabel 3, dapat kita lihat bahwa rasio kompresi LZSS terhadap file teks Canterbury Corbus tidak terlalu bervariasi. Hal tersebut dikarenakan kelimafile teks tersebut memiliki karakteristik yang hampir sama yaitu sebuah karya tulis non ilmiah dan ukuran file tidak jauh berbeda.

Dari hasil pengujian pada Tabel 3, diketahui bahwa semakin besar filemasukan semakin lama waktu pengompresian file teks tersebut. 


\subsubsection{Pengujian Rasio dan Durasi Kompresi pada File TeksLain}

Hasil pengujian rasio dan durasi kompresi padafile teks lain ditunjukkan pada Tabel 4.

Tabel 4. Hasil Pengujian Rasio dan DurasiKompresiFile TeksLain

\begin{tabular}{|c|c|c|c|c|}
\hline Kode & $\begin{array}{c}\text { Ukuran Sebelum } \\
\text { Kompresi (byte) }\end{array}$ & $\begin{array}{c}\text { Ukuran Setelah } \\
\text { Kompresi (byte) }\end{array}$ & Rasio (\%) & $\begin{array}{c}\text { Durasi } \\
\text { (ms) }\end{array}$ \\
\hline P1 & 5562768 & 4134071 & 74 & 6000 \\
\hline P2 & 3832502 & 2272557 & 59 & 6000 \\
\hline P3 & 2403653 & 1884993 & 78 & 3000 \\
\hline P4 & 3596723 & 2855648 & 79 & 5000 \\
\hline P5 & 2926192 & 1927907 & 66 & 3000 \\
\hline P6 & 284672 & 135258 & 48 & 937 \\
\hline P7 & 333824 & 107555 & 32 & 1000 \\
\hline P8 & 59392 & 17964 & 30 & 141 \\
\hline P9 & 2173034 & 1495575 & 69 & 1000 \\
\hline P10 & 718848 & 305332 & 42 & 1000 \\
\hline
\end{tabular}

Dari hasil pengujian padatabel 4, dapat kita lihat bahwa rasio kompresi LZSS terhadap file teks lainmemiliki nilai bervariasi. Hal tersebut dikarenakan kesepuluhfile teks tersebut memiliki karakteristik yang berbeda dan ukuran fileteks variatif.

Sama halnya dengan hasil pengujian padatabel 3, diketahui bahwa semakin besar filemasukansemakin lama waktu pengompresian file teks tersebut.

\subsubsection{Pengujian Rasio dan Durasi Kompresi pada File Teks Berformat .txt}

Pada pengujian ini diambil 3 file teks dari data yang sebelumnya diuji yaitu alice29.txt, james.doc, dan frogs.doc. File teks yang belum berformat .txt dikonversi terlebih dahulu. Berikut hasil pengujian rasio kompresifile teks berformat .txt ditunjukkan pada Tabel 5.

Tabel 5 Hasil Pengujian Rasio dan DurasiKompresiFile Teks Berformat .txt

\begin{tabular}{|c|c|c|c|c|}
\hline File & $\begin{array}{c}\text { Ukuran Sebelum } \\
\text { Kompresi(byte) }\end{array}$ & $\begin{array}{c}\text { Ukuran Setelah } \\
\text { Kompresi(byte) }\end{array}$ & Rasio (\%) & $\begin{array}{c}\text { Durasi } \\
\text { (ms) }\end{array}$ \\
\hline alice29.txt & 152089 & 73122 & 48 & 453 \\
\hline frogs.txt & 183586 & 66269 & 36 & 515 \\
\hline james.txt & 15433 & 8296 & 54 & 48 \\
\hline
\end{tabular}

Dari Tabel 5 didapatkan bahwa hasil rasio kompresi LZSS terhadap file teks berformat .txt baik jika filemasukannya berukuran besar seperti ditunjukkan frogs.txt menghasilkan rasio $36 \%$ dimana file asli teks tersebut sebesar 183586 byte.

Sama halnya dengan hasil pengujian pada Tabel 3 dan Tabel 4, diketahui bahwa semakin besar filemasukan semakin lama waktu pengompresian file teks tersebut.

\subsubsection{Pengujian Rasio dan Durasi Kompresi pada File Teks Berformat .doc}

Berikut hasil pengujian rasio kompresifile teks berformat .doc ditunjukkan pada Tabel 6.

Tabel 6 Hasil Pengujian Rasio dan Durasi KompresiFile Teks Berformat .doc

\begin{tabular}{|c|c|c|c|c|}
\hline File & $\begin{array}{c}\text { Ukuran Sebelum } \\
\text { Kompresi (byte) }\end{array}$ & $\begin{array}{c}\text { Ukuran Sesudah } \\
\text { Kompresi (byte) }\end{array}$ & Rasio (\%) & $\begin{array}{c}\text { Durasi } \\
\text { (ms) }\end{array}$ \\
\hline alice29.doc & 242176 & 103305 & 43 & 610 \\
\hline frogs.doc & 333824 & 107555 & 32 & 812 \\
\hline james.doc & 59392 & 17964 & 30 & 156 \\
\hline
\end{tabular}

Dari Tabel 6 didapatkan bahwa hasil rasio kompresi LZSS terhadap file teks berformat .doc mengalami peningkatan dibanding dengan kompresifile teks berformat .txt. 
Sama halnya dengan hasil pengujian pada Tabel 3, Tabel 4dan Tabel 5, diketahui bahwa semakin besar file masukan semakin lama waktu pengompresian file teks tersebut.

\subsubsection{Pengujian Rasio dan Durasi Kompresi pada File Teks Berformat .pdf}

Berikut hasil pengujian rasio kompresifile teks berformat .pdf ditunjukkan pada Tabel 7.

Tabel 7 Hasil Pengujian Rasio dan Durasi KompresiFile Teks Berformat .pdf

\begin{tabular}{|c|c|c|c|c|}
\hline File & $\begin{array}{c}\text { Ukuran Sebelum } \\
\text { Kompresi (byte) }\end{array}$ & $\begin{array}{c}\text { Ukuran Setelah } \\
\text { Kompresi (byte) }\end{array}$ & Rasio (\%) & $\begin{array}{c}\text { Durasi } \\
\text { (ms) }\end{array}$ \\
\hline alice29.pdf & 546470 & 469032 & 86 & 1000 \\
\hline frogs.pdf & 489807 & 449186 & 92 & 859 \\
\hline james.pdf & 140115 & 145613 & 104 & 187 \\
\hline
\end{tabular}

Sama halnya dengan hasil pengujian pada tabel 5, hasil rasio kompresi LZSS terhadap file teks berformat .pdf baik jika file masukannya berukuran besar seperti ditunjukkan alice29.pdf menghasilkan rasio $86 \%$ dimana file asli teks tersebut sebesar 546470 byte.

Sama halnya dengan hasil pengujian pada tabel 3,4,5dan6, diketahui bahwa semakin besar filemasukan semakin lama waktu pengompresianfile teks tersebut.

\subsubsection{Pengujian Dekompresi pada File Teks Berformat .txt Terkompresi Algoritma LZSS}

Pada pengujian dilakukan dekompresi dari file teks terkompresi algoritma LZSS ke file teks asal. Pengujian ini hanya dilakukan pada 3 file teks berformat yang sebelumnya diuji berdasarkan format. Berikut hasil dari dekompresifile teks ini ditampilkan pada tabel 8.

Tabel 8 Hasil Pengujian DekompresiFile Teks Berformat .txt terkompresi Algoritma LZSS

\begin{tabular}{|c|c|c|c|}
\hline File & Ukuran Kompresi (byte) & Hasil Dekompresi (byte) & $\begin{array}{c}\text { Durasi } \\
\text { (ms) }\end{array}$ \\
\hline alice29.txt & 73122 & 152089 & 297 \\
\hline frogs.txt & 66269 & 183586 & 265 \\
\hline james.txt & 8296 & 15433 & 47 \\
\hline
\end{tabular}

Dari tabel 8 diketahui bahwa file yang telah terkompresi dapat didekompresi ke file teks asal dengan baik dan ukuranfile juga sama dengan file teks asal sebelum terkompresi.

\subsubsection{Rata-rata rasio kompresi setiap pengujian}

Berikut rata-rata rasio kompresi dari setiap pengujian ditampilkan pada tabel 9.

Tabel 9 Rata-Rata Rasio Kompresi

\begin{tabular}{|l|l|}
\hline Pengujian Pada & Rata-Rata Rasio Kompresi \\
\hline Canterbury & $50 \%$ \\
\hline File Teks Lain & $57,7 \%$ \\
\hline Format .txt & $46 \%$ \\
\hline Format .doc & $35 \%$ \\
\hline Format .pdf & $94 \%$ \\
\hline
\end{tabular}

\subsubsection{Rata-rata Durasi kompresi setiap pengujian}

Berikut rata-rata durasikompresi dari setiap pengujian ditampilkan pada tabel 10 . 
Tabel 10 Rata-Rata Rasio Kompresi

\begin{tabular}{|l|l|}
\hline \multicolumn{1}{|c|}{ Pengujian Pada } & \multicolumn{1}{c|}{ Rata-Rata Durasi Kompresi } \\
\hline Canterbury & $2443,8 \mathrm{~ms}$ \\
\hline File Teks Lain & $2707,8 \mathrm{~ms}$ \\
\hline Format .txt & $427,34 \mathrm{~ms}$ \\
\hline Format .doc & $516 \mathrm{~ms}$ \\
\hline Format .pdf & $682 \mathrm{~ms}$ \\
\hline
\end{tabular}

\section{KESIMPULAN}

Berdasarkan hasil penelitian yang diperoleh dari pengujian aplikasi didapatkan kesimpulan sebagai berikut :

1. Aplikasi kompresi file menggunakan metode Lempel Ziv Storer Szymanski mampu mengompresi maksimaldengan rasio terbaik dari hasil pengujian didapat dari filemasukan berformat *.doc yaitu james.doc dengan rasio kompresi $30 \%$.

2. Kecepatan kompresi dipengaruhi oleh ukuran filemasukannya. Jika file masukannya berukuran besar maka pengompresian memakan waktu yang lama merujuk pada tabel 3, 4,5, 6dan 7 .

3. Dari hasil pengujian berbagai format, file teks berformat .doc menghasilkan rasio yang baik dengan rata-rata rasio kompresi $35 \%$ dan file teks berformat .txt menghasilkan durasi kompresi yang cepat dengan rata-rata durasi kompresisi 427,34 ms.

4. Dari hasil pengujian dekompresi diketahui bahwa file teks terkompresi dapat dikompresi ke file teks asli dengan baik. Ukuran file teks hasil dekompresisama dengan file teks asal sebelum terkompresi artinya kompresi LZZS yang digunakan benar lossless.

\section{DAFTAR RUJUKAN}

[1] D. Solomon, " Data Compression: the complete reference," Springer-Verlag: New York, 2004.

[2] J.A. Storer dan T.G. Szymaski, " Data compression via textual substitution, " Jurnal ACM on Information Theory, 1982.

[3] M. Powell, " Evaluating lossless compression method, " Technical Report, Department of Computer Science, University of Canterbury, NZ, 2004

[4] J. Gilchrist, "Archive Comparison Test, " Technical Report, 2002. http://compression.ca/ 